\title{
Response of physical parameters of tomato against various kinds of packaging materials
}

\author{
Ankush Chandla*, Kulveer Singh Yadav, Monika and Sachin Kishor \\ School of Agricultural Sciences and Technology, R.I.M.T. University, Mandi Gobindgarh (Punjab) India \\ Email: ankushchandla17@gmail.com)
}

\section{SUMMARY :}

The present study was conducted in Horticulture Lab at School of Agricultural Sciences and Technology, RIMT University, Mandi Gobindgarh, Punjab, India. This investigation was done to study the effect of different types of packaging materials on shelf-life, quality and storage of tomato cv. Heemsohna during the year 2020. The results revealed that out of the seven treatments, the treatment $\mathrm{T}_{4}$ (Black Polythene) showed best result as compared to other treatments except treatment $\mathrm{T}_{3}$ (Yellow Polythene) were recorded highest fruit weight, fruit length, fruit diameter and fruit $\mathrm{pH}$. Thus, it can be concluded that packaging of tomato fruits in polyethylene bags resulted in longer shelf-life and improved quality of the produce followed by packaging in black polythene bags. It was concluded that tomatoes wrapped in polyethylene bags were better in quality with longer shelflife.

KEY WORDS : Packaging material, Black polythene, Yellow polythene, Heemsohna

How to cite this paper : Chandla, Ankush, Yadav, Kulveer Singh, Monika and Kishor, Sachin (2020). Response of physical parameters of tomato against various kinds of packaging materials. Internat. J. Proc. \& Post Harvest Technol., 11(2) : 27-33. DOI: 10. 15740/HAS/IJPPHT/11.2/27-33. Copyright@2020: Hind AgriHorticultural Society. 